by Tao Wang ${ }^{\text {* }, \text { Reimar Seltmann }{ }^{2} \text {, He Huang }}{ }^{l}$, Ying Tong ${ }^{l}$, Dmitry Gladkochub ${ }^{3}$, Suzanne Y.

$\mathrm{O}^{\prime}$ Reilly $^{4}$, Cees van Staal ${ }^{5}$, Zengqian Hou ${ }^{1,6}$, Inna Safonova ${ }^{7,8}$, and Wenjiao Xiao ${ }^{9}$

\title{
Orogen architecture and crustal growth from accretion to collision (IGCP\#662): scientific activities 2018-2019
}

\author{
${ }^{1}$ Beijing SHRIMP Centre, Institute of Geology, Chinese Academy of Geological Sciences, No. 26, Baiwanzhuang Road, Beijing 100037, China; \\ *Corresponding author, E-mail: taowang@pku.edu.cn \\ ${ }^{2}$ The Natural History Museum, Earth Sciences Department, Centre for Russian and Central EurAsian Mineral Studies, London, UK \\ ${ }^{3}$ Institute of the Earth's Crust, Siberian Branch, RAS, Irkutsk, Russia \\ ${ }^{4}$ Macquarie University, ARC Centre of Excellence for Core to Crust Fluid Systems and GEMOC ARC National Key Centre, Sydney, Australia \\ ${ }^{5}$ Geological Survey of Canada, Ottawa, Canada \\ ${ }^{6}$ National Natural Foundation of China, Beijing, China \\ ${ }^{7}$ Sobolev Institute of Geology and Mineralogy SB RAS, Novosibirsk, Russia \\ ${ }^{8}$ Novosibirsk State University, 1 Pirogova St., Novosibirsk, 630090, Russia \\ ${ }^{9}$ Xinjiang Research Center for Mineral Resources, Xinjiang Institute of Ecology and Geography, Chinese Academy of Sciences, Urumqi \\ 830011, China
}

(Received: September 11, 2019; Revised accepted: April 18, 2020)

https://doi.org/10.18814/epiiugs/2020/020061

The scientific board of the International Geoscience Programme (IGCP), jointly sponsored by IUGS and UNESCO, approved for funding in March 2018 the IGCP-662 project (2018-2023) entitled "Orogenic architecture and crustal growth from accretion to collision". Four meetings and field excursion, as well as training courses, have been successfully held respectively in 2018 and 2019. The first workshop was held during $21^{\text {th }}-22^{\text {nd }}$ September 2018 in Beijing, China, with a 5-day (15th - 19th September) preworkshop field trip and one-day (23 September 2018) post-conference training course on "Using isotopes in zircon and sulfides to understanding crust-mantle evolution". The second workshop and field trip of the IGCP-662 project were held in Mongolia from July 4th - 10th, 2019. Besides, the IGCP-662 project joined as co-sponsor the organization of an international symposium "The Geology of Eurasia" held at the Helmholtz-Centre Potsdam - German Research Centre for Geosciences (GFZ) during $26^{\text {th }}$ June

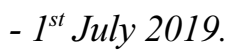

\section{Introduction}

The IGCP-662 project (Orogenic architecture and crustal growth from accretion to collision, 2018-2023) was approved in March 2018 and supported since then by the International Geoscience Programme (IGCP). The major work of the project includes: (1) conducting comparative studies of crustal compositions and architecture of the CAOB (Central Asia Orogenic Belt) and Tethyan belt, as well as several others, including the Central China Orogenic System (CCOS),
North American Appalachians and Australian Lachlan orogen; (2) undertaking regional isotopic mapping of targeted igneous rocks in typical regions, delineating juvenile or reworked ancient crustal provinces; (3) identifying and describing orogenic types and their development by area ratios of the different-type crustal provinces. The above goals are based on previous work, including research by the proposers (now the leaders of the project), in some typical orogens, such as the CAOB, the Tibetan Plateau, and the Central China Orogenic System.

The IGCP-662 project perfectly serves as an information and communication platform between leadership and participants including a significant number of postgraduate students and early-career researchers (ECRs). Since its launch, the project has organized many academic activities (see the webpage www.igcp662.org.cn for details). Some major activities are reported here.

\section{IGCP\#662 Related Academic Meetings in 2018}

\section{Meeting \#1: "First Workshop, Field Excursion in China"}

The first workshop was held during $21^{\text {th }}-22^{\text {nd }}$ September 2018 in Beijing, China, including 5-day (15th -19th September) pre-workshop field trip to the Dunhuang Block and Beishan Orogen in the DunhuangLiuyuan area, southern Central Asian Orogenic Belt, NW China, furthermore a 2-day workshop and a 1-day training course. About 100 participates from China, Canada, France, Israel, Mongolia, Russia, the Republic of Korea and Turkey took part in the field excursions. Prof. Jinfa Li, Deputy Director of China Geological Survey, also took part in the first workshop and field trip. 


\section{Pre-conference field excursion in Dunghuan-Beishan, China}

The field trip included two excursions in the Dunhuang and Liuyuan area, southern Central Asian Orogenic Belt (CAOB), organized by Cees van Staal and Shoufa Lin (Canada) and sponsored by the Institute of Geology, Chinese Academy of Geological Sciences. The excursion in the Dunhuang Block was led by Wenhua Ji, Lei Kang, and Jianguo Yang from the Xi' an Center, China Geological Survey. Participants visited the basement of the Dunhuang block as well as a Precambrian sedimentary-volcanic cover sequence and Paleozoic intrusions on the northeastern margin of the Dunhuang Block, which was investigated by the Xi'an Center, China Geological Survey in 2017-2018 as part of a 1: 50,000 scale mapping project. Participants examined the Paleoproterozoic Dunhuang Group basement (Pt1D), the Neoproterozoic-Early Cambrian sedimentary-volcanic cover sequence and early Paleozoic intrusive rocks and obtained a preliminary understanding of the composition, compositional variation and metamorphic and structural characteristics of the basement, the sedimentary cover and the intrusive rocks of the Dunhuang Block, and discussed the boundary of the southern margin of the Central Asian Orogenic Belt with the Trim Craton.

The field trip in the Liuyuan area, Beishan Orogen, was led by Cees van Staal, Tong Hong and Shoufa Lin from the University of Waterloo, Canada. Participants visited the Beishan Orogen at the southern margin of the Central Asian Orogenic Belt, an area immediately south of the town of Liuyuan, and gained an overview of the tectono-stratigraphy and deformation history of part of the Beishan orogen. The area was also investigated by Cees van Staal and Shoufa Lin in 2016-2018 as part of the 1:25,000 scale mapping exercise with the China Geological Survey.

\section{Workshop in Beijing}

The first workshop was held during September 21-22, 2018 in Beijing, China. The conference was sponsored by the Institute of Geology, Chinese Academy of Geological Sciences. A total of 86 participants, including professors, young scientists and graduate students from 13 countries, including Germany, Australia, Russia, Mongolia, Turkey, France, Canada, the United Kingdom, Pakistan, Turkey, Russia, Korea, Israel and China attended the conference. Prof. Tao Wang, leader of the project, took charge of the conference. Prof. Jinfa Li, Academician Zengqian Hou (vice-president of the National Natural Science Foundation of China), and Prof. Qiuming Cheng (president of IUGS) gave welcoming addresses. Prof. Tao Wang gave a brief introduction to the project during the opening ceremony. Subsequently, there were 24 oral presentations to show the research results of ophiolites, orogenic architecture, crustal growth, tectonic evolution of different orogens in the world, including the Central Asian Orogenic Belt in China, Mongolia, Russia, Pacific belt in Korea, Jiangnan orogen in south China, Appalachian in Canada, Lachlan fold belt in Australia, Tethyan belt in China and Turkey. In addition, 14 poster presentations were discussed. Subsequently, six professors gave four fantastic courses on "Using isotopes in zircon and sulfides to understanding crust-mantle evolution" on September 23, 2018.

Some representative oral presentations are listed below: "Orogenic Architecture and Crustal Growth from Accretion to Collision: An
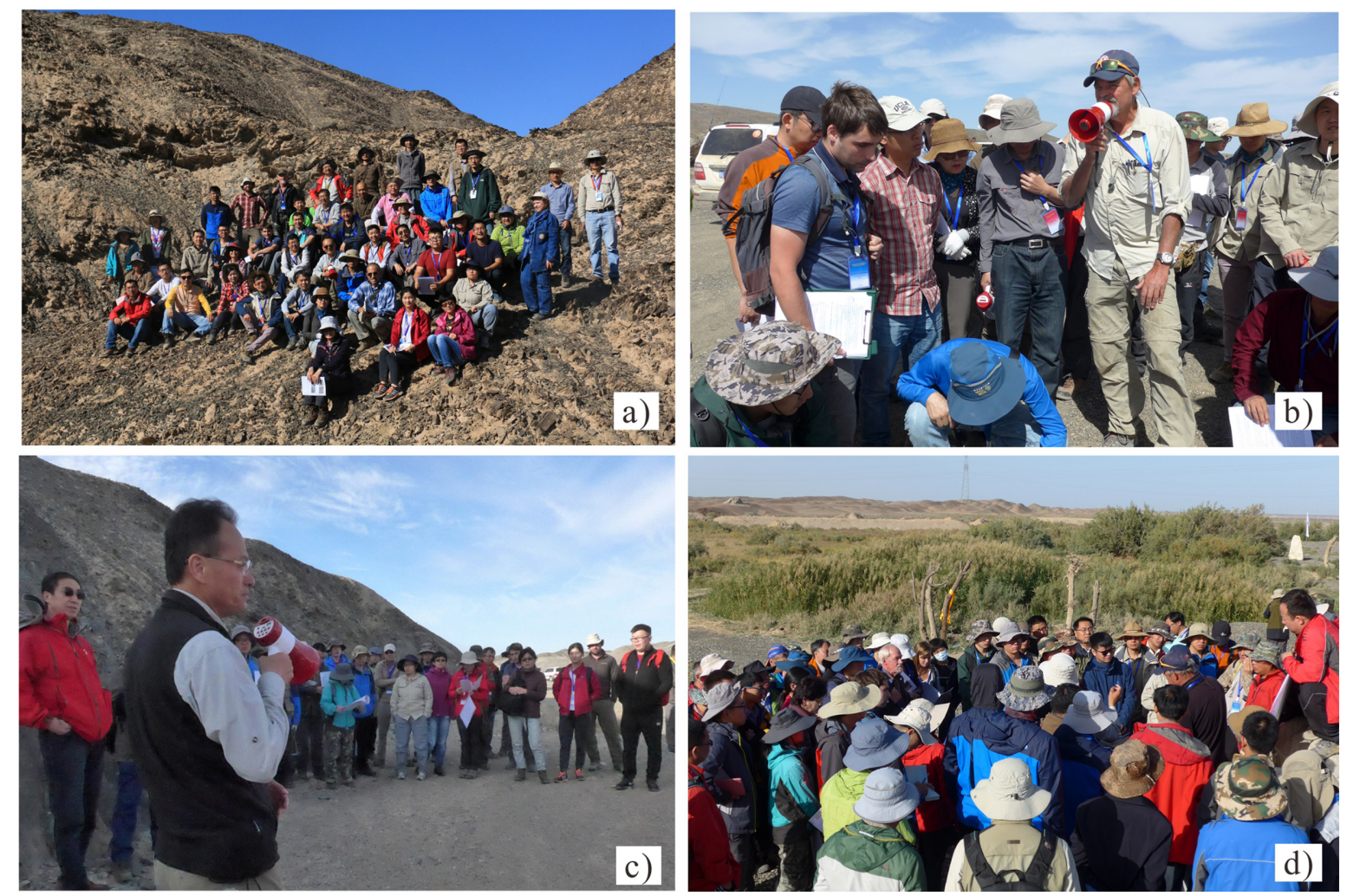

Figure 1. Photos during the pre-conference field trip of the first workshop. (a) A group photo in the field trip; (b) and (c). Prof. Cees van Staal (a) and Shoufa Lin introduced the field geology and showed the results of geological mapping by him and colleagues; (c) Participants listen carefully to the introduction by Prof. Cees van Staal. 


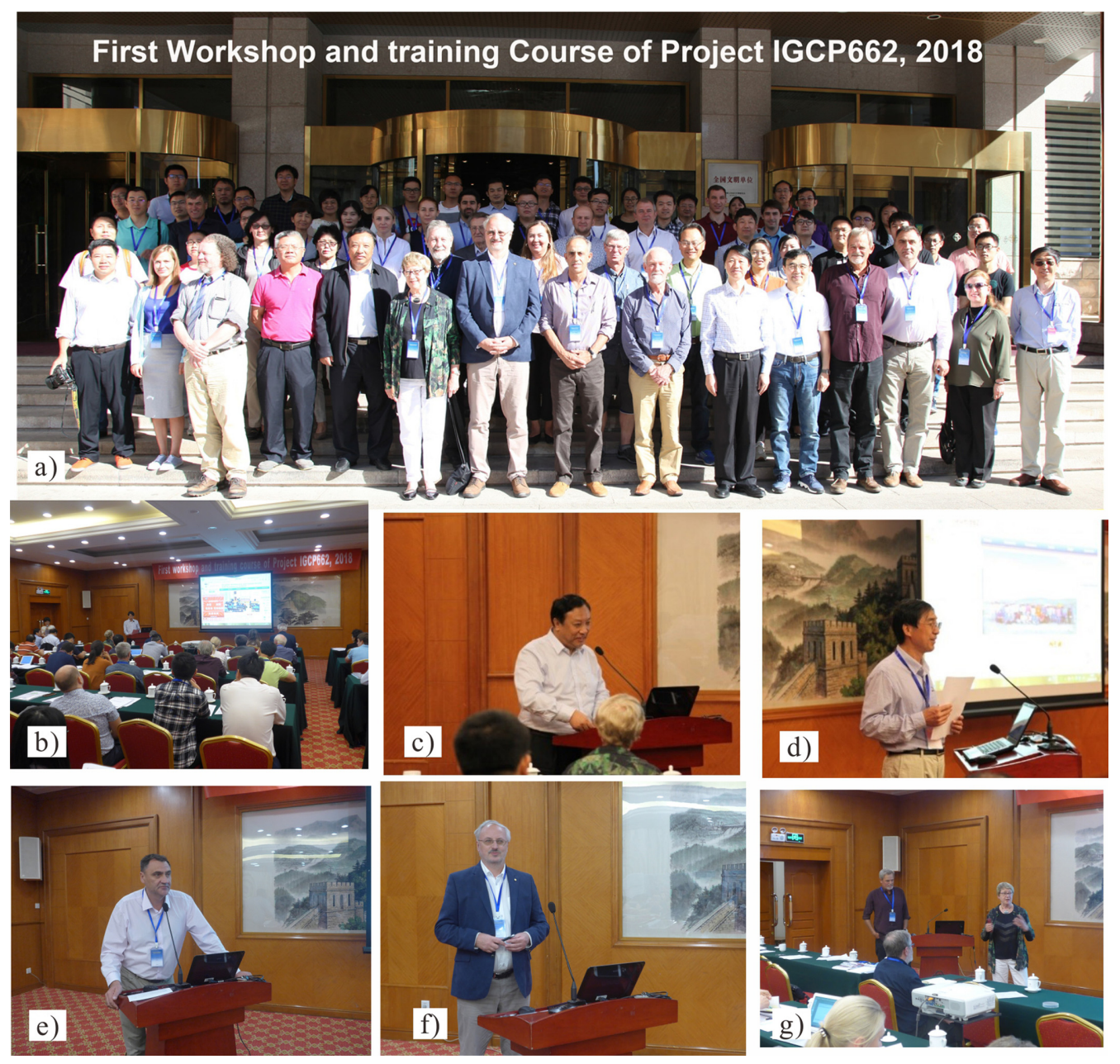

Figure 2. Photos from the first workshop of the IGCP-662 project. (a) Group photo during the workshop; (b) Prof. Jinfa Li, deputy director of China Geological Survey gave a speech; Academician Zengqian Hou, Deputy director of the National Natural Science Foundation of China, IGCP-coleader gave an address; (d) Prof. Tao Wang, the leader of the IGCP 662 project, introduced the IGCP-662 project and gave a talk; (e) Prof. Dmitry Gladkochub and (f) Prof. Reimar Seltmann giving oral presentations; (g) Prof. Suzanne Y. O'Reilly answered questions after her oral presentation, hosted by Prof. Cees van Staal.

introduction of IGCP-662" by Tao Wang; "Paleoproterozoic orogenic events and metallogeny of the Aldan shield of the southern Siberian craton" by Dmitry Gladkochub; "Mineral Assessment of Western CAOB Revisited" by Reimar Seltmann; "Subduction Processes of the PaleoAsian Ocean in the Alxa Tectonic Belt (NW China)" by Dongfang Song and Wenjiao Xiao; "The Xing-Meng Intracontinent Orogenic Belt" by Bei Xu; "UHP versus super-reducing parageneses in Tibetan ophiolites" by William Griffin; "Complications in interpreting zircon ages from polymetamorphic terranes" by Alfred Kröner; "Magmatic Evolution of the Northern Cache Creek Terrane, British Columbia and Yukon, Canadian Cordillera" by Jean Bédard; "South China as an accretionary orogen" by Shou-Fa Lin; "Accretionary history of the northern Appalachian Orogen" by Cees Van Staal; "Geodynamic processes during heroic collisions: integration of geochemical, microstructural and geodynamic information" by Suzanne Y. O'Reilly.

\section{Post-conference Training Courses}

Post-conference training courses on "Using isotopes in zircon and sulfides to understanding crust-mantle evolution" were held on Septem- ber 23, 2018 in Beijing. More than 70 young researchers and students took part in this training course. Prof. Yusheng Wan from the Beijing SHRIMP Centre gave a lecture "Hadean to Palaeoarchaean rocks and zircons in China”. Prof. Alfred Kröner, from the University of Mainz, Germany and the Beijing SHRIMP Centre, spoke about "Complexities in interpreting zircon ages from polymetamorphic terranes". Prof. Suzanne Y. O'Reilly and Prof. Willian Griffin from Macquarie University in Sydney, Australia, delivered "Tracing crustal evolution and crust-mantle linkages with zircon Hf isotopes" and "Re-Os isotopes and the subcrustal mantle lithosphere", respectively. Prof. Simon A. Wilde of Curtin University talked about the careful interpretation of zircon dating results. Dr. Jean Bédard from the Canadian Geological Survey delivered a course about ophiolite.

\section{IGCP\#662 Related Meetings in 2019}

\section{Meeting \#2: Joining EGU and Organizing a Session}

The European Geosciences Union (EGU) holds its annual scien- 

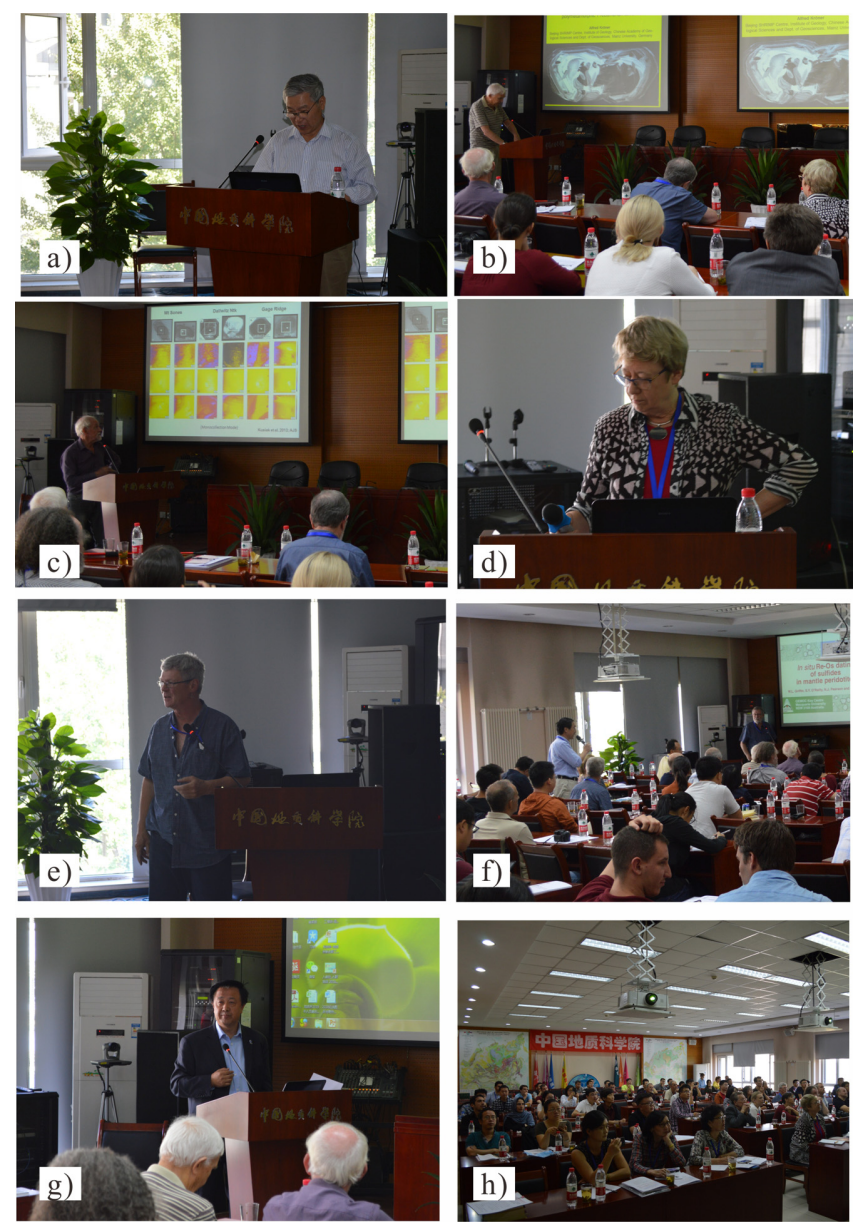

Figure 3. Photos from the post-conference training courses. (a) Prof. Yusheng Wan, (b) Prof. Alfred Kröner, (c) Prof. Simon A. Wilde, (d) Prof. Suzanne Y. O'Reilly and (f) Dr. Jean Bédard, who were giving their lectures; (g) Prof. Willian Griffin, discussing with the audience after his lecture; (h) Prof. Qiuming Cheng, the president of the IUGS (International Union Geological Society) gave an address; (i) More than 70 young researchers and students taking part in this training course.

tific meeting in the form of the General Assembly. The EGU 2019 was held from $7^{\text {th }}$ to $12^{\text {th }}$ April 2019 at the international conference center in Vienna, Austria. A total of 16,273 researchers from 113 countries and regions participated in the conference and presented a total of 5,531 orals and 9,432 posters, and 1,287 PICO presentations. Ying Tong, secretary-general of IGCP-662 and some core members of the project, including Jianjun Zhang, Peng Song and Pengfei Li, attended the meeting.

\section{Participating in IGCP Project Leaders' Meeting}

Drs. Ying Tong, Jianjun Zhang and Peng Song, from the Institute of Geology, CAGS and Dr. Pengfei Li, from the Guangzhou Institute of Geochemistry, Chinese Academy of Sciences (CAS), representing the IGCP-662 project team, participated in the meeting of IGCP project leaders organized by UNESCO/IUGS/CGMW. The meeting was presided by Özlem Adiyaman, who first introduced the newly approved IGCP projects in 2019. After that, each participating IGCP project introduced its own work program. Secretary general Ying Tong, on behalf of IGCP-662 project leader Tao Wang, introduced the fundamental scientific questions of the IGCP-662 project and described the progress of the project achieved during 2018-2019, highlighting the extensive communication among participants, including discussing with chief editor and editors of Episode the application for launching a special issue of IGCP-662.

\section{Organizing special topics}

In cooperation with IGCP Project 662, the EGU session "Accretion, collision and oroclinal bending in the Late Paleozoic: linking with the supercontinental evolution (TS7.5/GD5.11)" was organized by Pengfei Li, Daniel Pastor-Galán, Karel Schulmann and Min Sun. Seven oral and 15 poster presentations were presented in the session, including an invited oral presentation by Prof. William Collins from Curtin University in Australia, entitled "Billion year cyclicity through Earth history: causes and consequences". In the X2 hall, IGCP-662 project team members Ying Tong, Pengfei Li, Jianjun Zhang and Peng Song presented the project exhibition and had fruitful communication with scientists from across the globe.

The participation of the IGCP-662 group in EGU 2019 was fairly helpful in showing the up-to-date achievements of the project, in particular the deep material exploration of orogenic belts by regionalscale isotopic mapping, and in building the foundation for the next step of cooperation with relevant institutes, universities, and international organizations worldwide. These achievements attracted a lot of attention of colleagues from all over the world, and thereby highlighted and enhanced the influence of the IGCP-662 project.

\section{Exchanging with IGCP-667 Project and CGMW Orga- nization}

The IGCP-662 project, together with the IGCP-667 project, carried out exchanges with the representatives of the Commission for the Geological Map of the World (CGMW) during the EGU 2019. Dr. Ying Tong introduced the IGCP-662 project and, on behalf of IGCP662 leaders, expressed the prospect of further cooperation, especially in fields such as the compilation of maps based on the global massive geoscience data, 3D map displays and the comprehensive comparative research on distinguishing the type, structures and compositions of orogenic belts. The two sides agreed to strengthen in-depth cooperation further.

\section{Meeting \#3: Joining International Symposium "The Geology of Eurasia” at GFZ Potsdam}

The IGCP-662 project joined as co-sponsor the organization of an international symposium "The Geology of Eurasia" held at the Helmholtz-Centre Potsdam - German Research Centre for Geosciences (GFZ) during the $26^{\text {th }}$ of June to 1st of July, 2019. The purpose of the participation as a co-organizer was to build bridges between the German scientific community and the IGCP-662 research network. The IGCP662 leaders Profs. Tao Wang, Reimar Seltmann, Inna Safonova and Wenjiao Xiao attended the symposium and gave talks on their research in progress. After the symposium, they participated in the field trip 

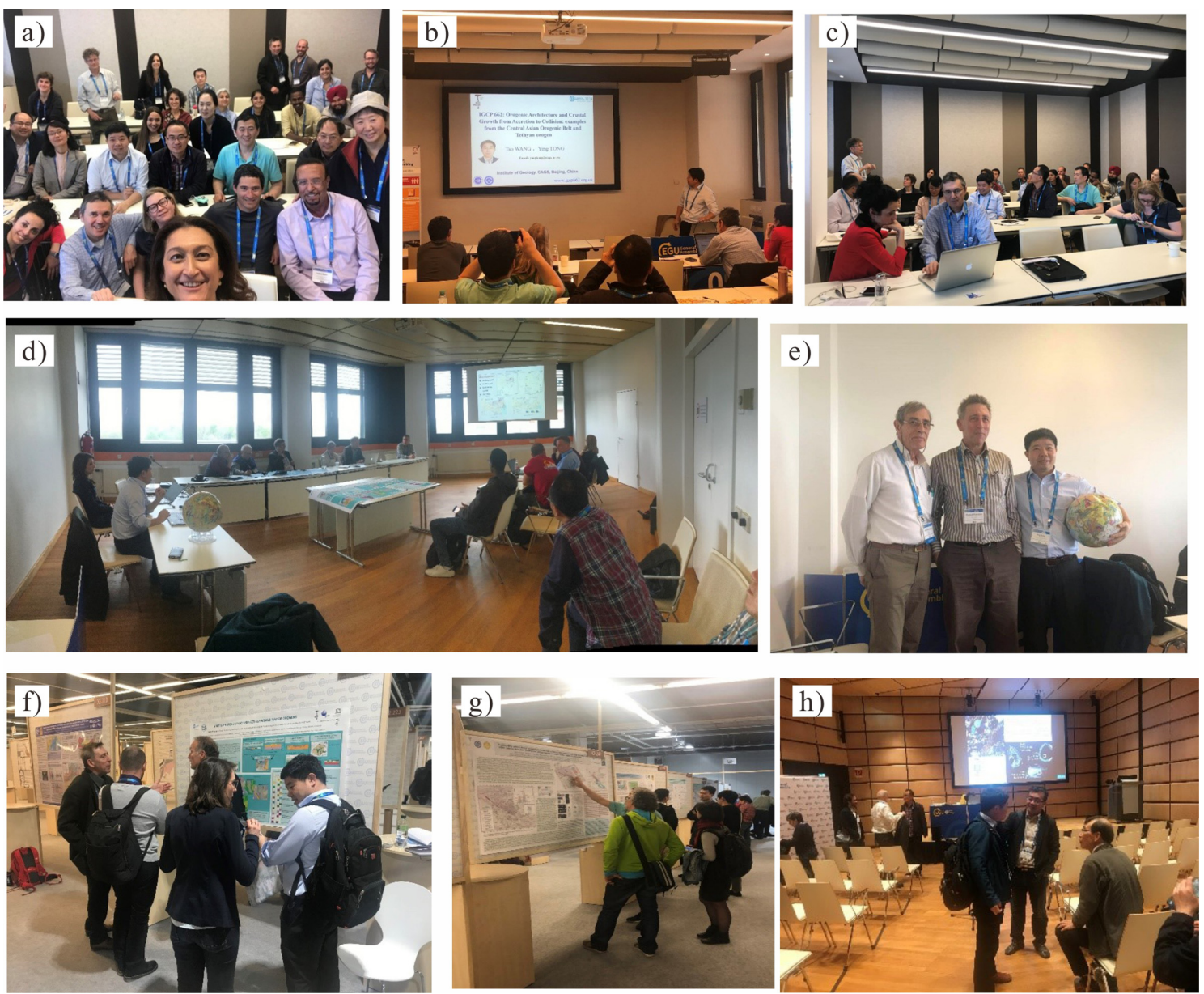

Figure 4. Photos from EGU 2019. (a) Group photo of participants in the session "Accretion, collision and oroclinal bending in the Late Paleozoic: linking with the supercontinental evolution (TS7.5/GD5.11)"; (b) Dr. Ying Tong introducing the IGCP-662 project; (c) Participants discussing in the session; (d-e) The IGCP-662 project and the IGCP-667 project exchanged work with the CGMW; (f-h) Discussions after the oral report and the communication in the panel area.

examining the Hercynian orogenic belt in German Erzgebirge to investigate the composition and magma evolution of the Hercynian orogenic belt. During the field trip, they also visited famous outcrops, including the type location where granulite was first recognized, named and studied.

\section{Meeting \#4: "Second Workshop and Field Excursion in Mongolia”}

The second workshop and field trip of the IGCP-662 project was held in Mongolia from July $4^{\text {th }}$ to $10^{\text {th }}, 2019$. A total of 80 participants from China, Mongolia, Russia, the Czech Republic, Australia, South Korea, Japan, Brazil, Pakistan and Vietnam attended the meeting. This workshop also contributed to the $60^{\text {th }}$ anniversary of the establishment of the Mongolian University of Science and Technology, and to the $80^{\text {th }}$ anniversary of the Mongolian Geological Survey. The Mongolian University of Science and Technology, the Institute of Paleontology \& Geology of the Mongolian Academy of Sciences (MAS), Institute of Astronomy and Geophysics of the MAS, the Czech Geological Survey and other institutions co-operated closely for organizing the workshop and field excursion.

The meeting was held at the Mongolian University of Science and
Technology in Ulaanbaatar and chaired by Prof. Ochir Gerel, Director of Geoscience Center at the Mongolian University of Science and Technology. The meeting began with a moment of silence for two of the recently passed away champions of geoscientific research of Mongolia: Prof. Alfred Kröner from Mainz University, Germany, and Academician Onongo Tomurtogoo of the Institute of Paleontology and Geology, Mongolian Academy of Sciences, in memory of their outstanding contributions to the geological research on the Central Asian Orogenic Belt (CAOB) and the education and mentoring of young scientists. The oral and poster presentations in the meeting displayed the latest progress in the fields of global crustal growth, Central Asian Orogenic Belt, Tethyan orogenic belt, Precambrian geology of Korean peninsula, Precambrian geology of Antarctica, active structure of Mongolia, etc. Participants engaged in in-depth discussions on formation, evolution and regional mineralization of different orogenic belts, and conducted extensive exchanges on the cooperation among various research teams and related institutes, achieving gratifying outcomes.

After the workshop, nearly 70 participants from 9 countries took part in a 5-day field trip to the southwest of Mongolia. Researchers investigated the Paleozoic rock assemblages and structures in the southwest of the Mongolian Lake Zone and Altai tectonic belts, including 

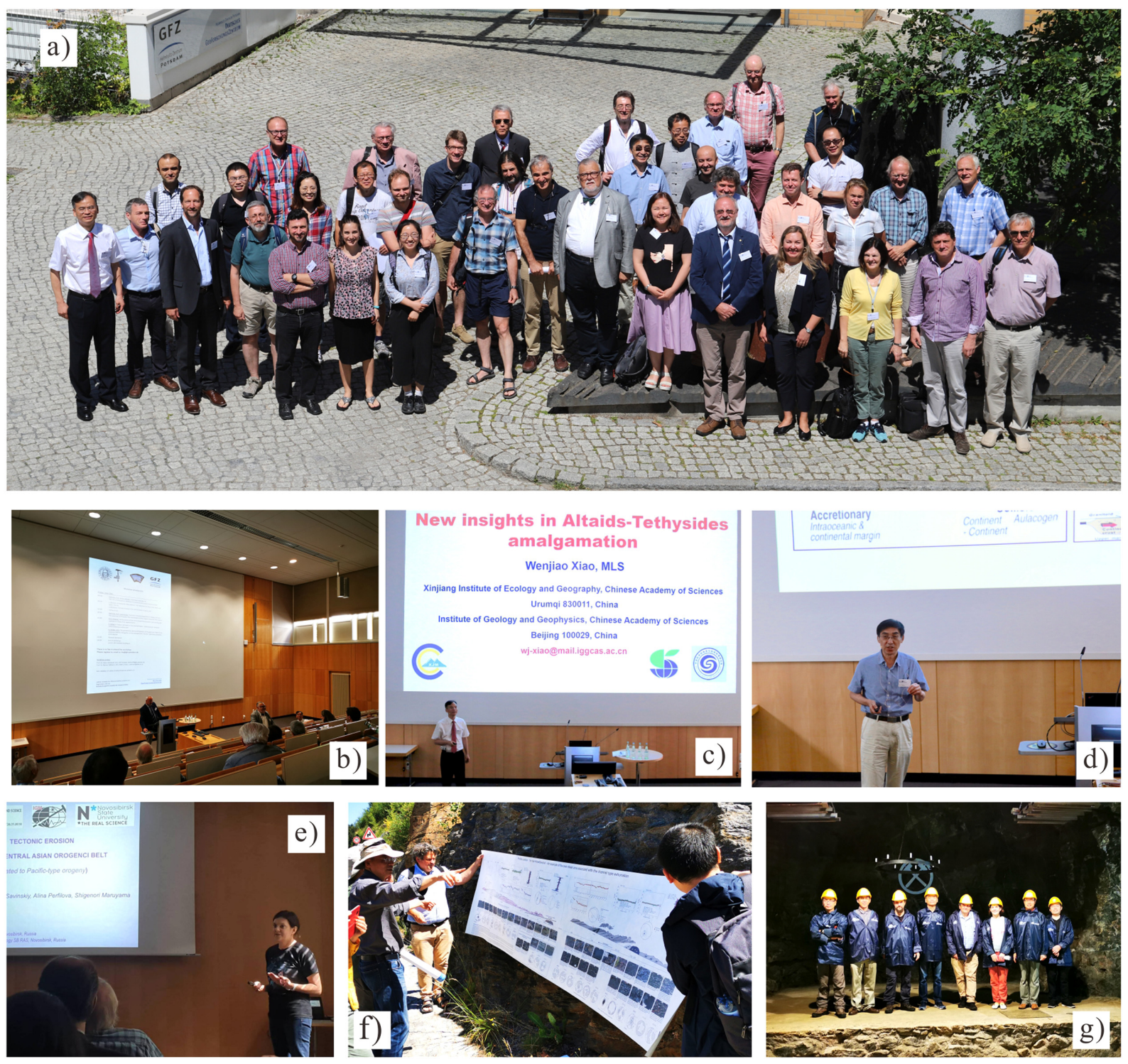

Figure 5. (a) Delegates photo at the GFZ in Albert Einstein Science Park, Potsdam; (b, $c$, d and e) the IGCP-662 leaders Profs. Reimar Seltmann, Wenjiao Xiao, Tao Wang and Inna Safonova gave talks; ( $f$ and g) Photos of field investigation in Erzgebirge part of the Hercynian orogenic belt and from underground mine visit.

the Erdene Uul ophiolite, Boomyn Khudag Cambrian molasse, Tsogt metamorphic complex with high-grade metamorphism, Khaya Khudag Cambrian arc gabbro, high-pressure mica schist, eclogite and Cambrian fossil-bearing limestone. During the field trip, Prof. Schulmann and Dr. Hanžl gave a detailed introduction to the mapping results of the cooperation between the Czech Republic and Mongolia over the past 20 years, and conducted full exchanges and discussions with researchers from different countries in the field. The field trip helped all participants to develop a deep understanding of the early evolution of the Central Asian Orogenic Belt, and expanded their knowledge of the composition and structural characteristics of accretionary orogenic belt as well.

\section{Joins DDE and Relative Activities}

International Union of Geological Sciences funded program Deeptime Digital Earth (DDE) is an IUGS-recognized International Big
Science Program that has set for 10 years' duration from 2019 to 2028 . It is a collaboration among international organizations and national geological surveys. DDE aims to (1) make available interoperable, internet-accessible, scientifically-attributable data either published in articles or in scientists' hand who want to make their data FAIR (Findable, Accessible, Interoperable and Re-usable) with proper recognition and accreditation; (2) to unite all Earth science communities around a single intellectual platform and to understand the full range of Earth-life process through 4E (Evolution of Life, Evolution of Geography, Evolution of Climate, Evolution of Materials) during the deep time. This process is vital for addressing urgent and future environmental and societal issues. DDE consists of more than 10 field-groups.

IGCP-662 actively participates in DDE. The first goal is to better publicize IGCP-662 so that more people know about, and participate in, IGCP. Another is to use DDE to promote the establishment of IGCP662 , especially to accelerate the establishment of isotopes and other related databases. Tao Wang, leader of the IGCP-662 project, and Ying 

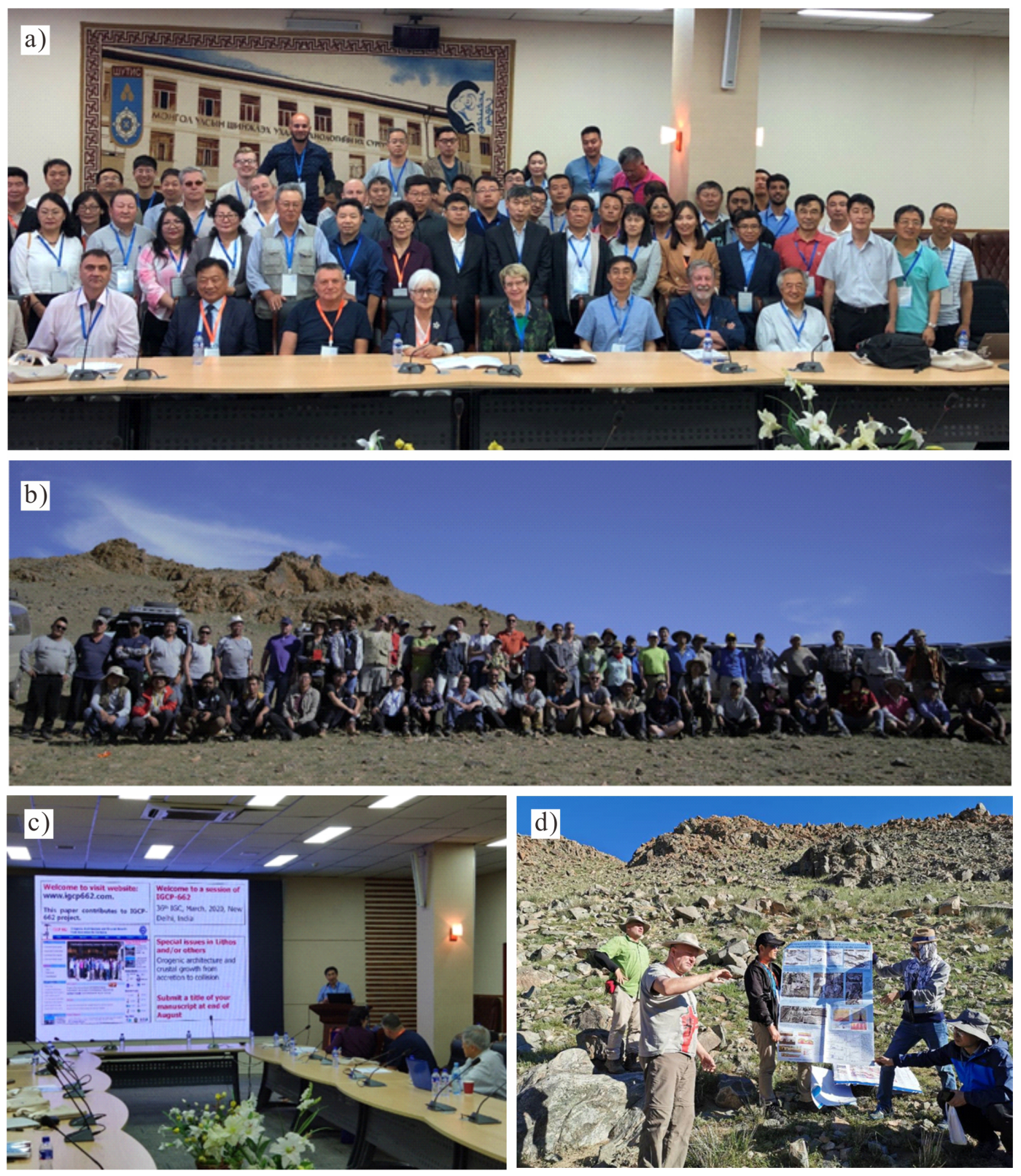

Figure 6. Photos from the second workshop of the IGCP-662 project. (a) Group photo of the participants; (b) Prof. Tao Wang, the leader of the IGCP-662 project, introduced the work plan of the IGCP-662 project for next year; (c) Prof. K. Schulmann and Dr. P. Hanžl from the Czech Geological Survey introduced the mapping results obtained over the past years; (d) Group photo during the field trip.

Tong, secretary-general, as the group leader of magmatic rocks and geochemistry in DDE, are organizing the construction of the knowledge tree for magmatic rocks. Reimar Seltmann and Wenjiao Xiao, co-leaders of the IGCP-662 project, organized the Central Asia regional database Working Group and lead the organization to build the database in this vast region.

\section{Summary}

Based on the scientific activities of the IGCP-662 project in 20182019 , important progress in studies on accretionary and collisional orogens has been achieved. The IGCP-662 project has gained worldwide attention, and more and more colleagues from different countries are taking part in the project. As the next steps, the IGCP-662 project will join the Deep-time Digital Earth (DDE), a large international program of the International Union of Geological Science (IUGS). IGCP-662 also has plans to undertake further research for comparative studies of different orogenic and metallogenic belts in the world. In 2020, the IGCP-662 project will organize a session "Orogenic architecture and crustal growth from accretion to collision (IGCP-662)" at the $36^{\text {th }}$ International Geological Congress (IGC) in New Delhi, India. In addition, small thematic working meetings and field trips in Vietnam and Russia are planned for next year. 


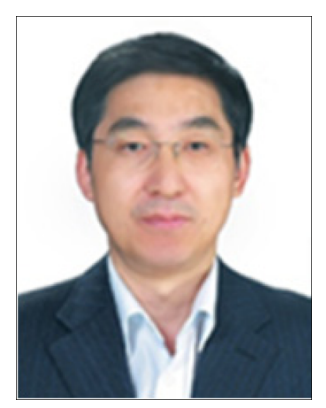

Tao Wang is a Professor (Senior Researcher) at the Institute of Geology, CAGS, Director of the Beijing SHRIMP center and Director of Committee of Experts of Geological Survey. His research interests are focused on the tectonics, granitoids, and continental growth in the Central Asian Orogenic Belt. Taking part in the 1:5M International Geological Map of Asia, he was in charge of granite map compilation and research, and finished a new magmatic map of Asia.

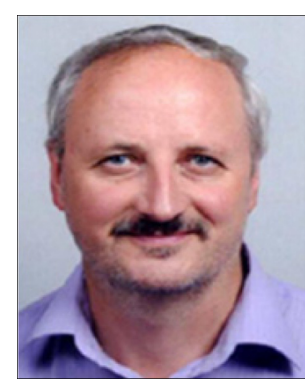

Reimar Seltmann is a Research Leader in the Department of Earth Sciences at the Natural History Museum, London, where he serves, since 2002, as Head of the Centre for Russian and Central EurAsian Mineral Studies (CERCAMS). He has been a co-/leader of many international projects (e.g., IGCP 373,473, 592, 662; research network "Metallogeny of the Altaids"). His research interests are petrology, geodynamics, metallogeny and mineral deposits, specifically of ore provinces in Europe and central Eurasia.

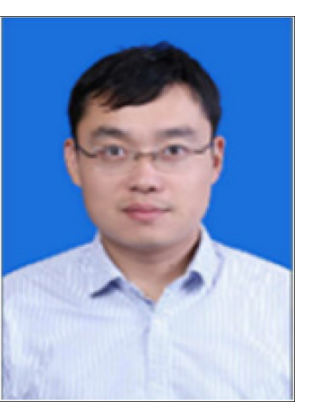

He Huang is an Associate Research Fellow at the Institute of Geology, Chinese Academy of Geological Sciences (CAGS). He obtained his Ph.D. degree from China University of Geosciences (Beijing) in 2013. His research interests focus on petrogenesis of igneous rocks from the Central Asian Orogenic Belt (CAOB) and Northern Tarim, plate tectonics and continental growth of the CAOB and rare metal metallogenesis of granitic system.

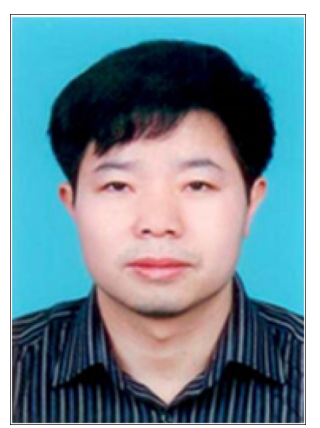

Ying Tong is an Professor at the Institute of Geology, CAGS. He obtained his Ph.D. degree from Chinese Academy of Geological Sciences in 2006. His research interests focus on relationships of tectonic and magmatic events during the late evolution stage of orogenic belts (first focus on Central Asian Orogenic Belt), geotectonics and petrogenesis of continental crust and origin of the A-type (alkaline) granite.

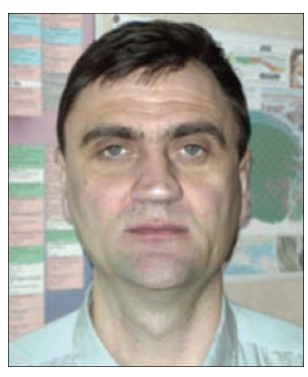

Dmitry Gladkochub is the Deputy Director at the Institute of Earth's Crust, Siberian Branch, Russian Academy of Sciences (SB RAS) Dmitry graduated with an MSc degree in Geology (1990), PhD in Geology (1997) and the DSc degree in Geodynamics and Geotectonics (2004). His research includes metamorphic and igneous petrology, regional geology, and tectonics with a special emphasis to the Precambrian evolution of the Siberian craton and supercontinent cycles. He has been involved in international collaborations and has organized meetings and workshops of IGCP Projects \#440 and \#480 in Russia.

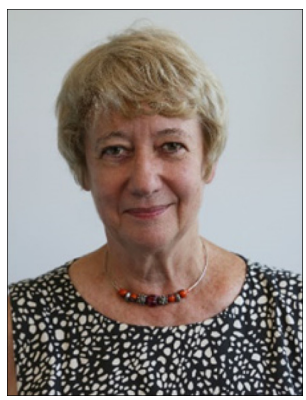

Suzanne Y. O'Reilly AM, Distinguished Professor Macquarie University is Director of the Australian Research Council Centre of Excellence for Core to Crust Fluid Systems and GEMOC, Fellow of the Australian Academy of Science and Clarivate highly cited researcher. She is internationally recognized as a pioneer in the integration of geophysical, geochemical, petrological, petrophysical and tectonic data to construct realistic lithospheric structure and evolution models (4-D Lithosphere Mapping) and understand whole-mantle dynamics through time to understand metallogenesis. Understanding the nature and evolution of our amazing planet in this way, has revolutionized the way mineral exploration is now done by progressive industry explorers.

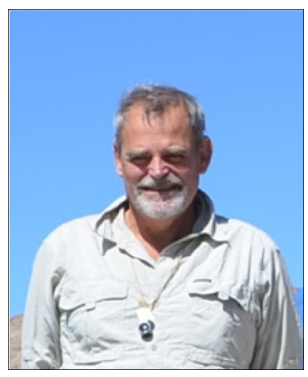

Cees van Staal is currently a senior visiting scholar at the Institute of Geology, Chinese Academy of Geological Sciences. Born in 1954, van Staal completed his Ph.D. degree at the University of New Brunswick (1984). He specialized in structural/metamorphic evolution of recent and ancient accretionary wedges/ subduction complexes, particularly the exhumation mechanisms of high pressure rocks during convergence. He is internationally recognized as a leading authority on the geology and tectonic evolution of the Appalachian-Caledonian Orogen, the paleogeography of Laurentia and West-Gondwana between 650 and $300 \mathrm{Ma}$ and orogenesis associated with arc-accretion.

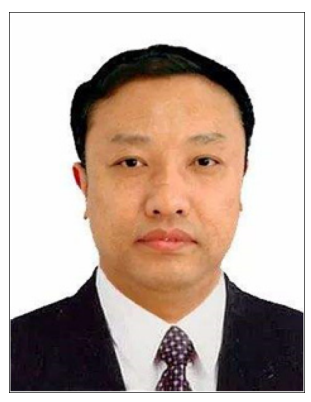

Zengqian Hou is a Professor (Senior Researcher) at the Institute of Geology, CAGS and currently Vice President of National Natural Science Foundation of China (NSFC). He obtained his $\mathrm{Ph}$.D. degree from China University of Geosciences in 1988. He has conducted several major projects including an IGCP project and two Chinese State Key 973 Fundamental Research Projects on the lithospheric architecture and relevant mineral systems in collisional orogenies. These researches have led to an establishment of a new theoretical framework and genetic models for collision-related metallogenesis (REE, $\mathrm{Cu}$, $\mathrm{Pb}-\mathrm{Zn}, \mathrm{Au}$ ), and major discoveries of world-class copper and other metallic deposits in China. He authored or co-authored about 280 refereed papers with more than 10,000 citations, and awarded several prestigious national and international awards. 


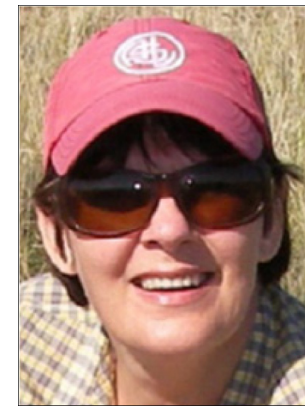

Inna Safonova is a Lab Chief in Novosibirsk State University (since 2017) and Senior Research Scientist at the Sobolev Institute of Geology and Mineralogy SB RAS, Novosibirsk, Russia (since 1991). She obtained Ph.D. (2005) from the Institute of Geology SB RAS. Her research fields include Pacific-type orogenic belts, continental growth in Central Asia, ocean plate stratigraphy, igneous geochemistry and petrology, geochronology, mantle plumes. She was the proposer and leader of GCP\#592 Project "Continental construction in the Central Asian Orogenic Belt compared with actualistic examples from the western Pacific" sponsored by UNESCO-IUGS (20122016).

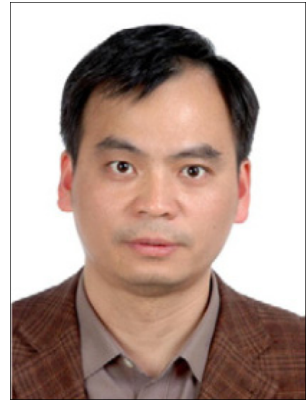

Wenjiao Xiao is a Professor of tectonics and structural geology at the Xinjiang Institute of Ecology and Geography, also at the Institute of Geology and Geophysics, Chinese Academy of Sciences (CAS). He received his $\mathrm{PhD}$ (1995) from the Institute of Geology, CAS. He finished his postdoc research at the Institute of Geophysics, CAS, in 1997. His primary research interests focus on tectonics and structural geology of the Altaid and Tethyan orogens, and comparative studies across Phanerozoic orogenic belts. He is a recipient of the National Natural Science Award (Second Prize, 2012) of China. 